\title{
Understanding the Artisanal Mining of the Pissy Granite Quarry Using the Problem-in-Context Framework (PiC)
}

\section{Michelline Marie Regina Kansole ${ }^{1 *}$, Moussa Compaore ${ }^{2}$, Anselme Bagoro ${ }^{3}$, Maryam Tamboura ${ }^{3}$, Kpiebote Palenfo ${ }^{3}$, Seta Naba ${ }^{4}$}

\author{
${ }^{1}$ University of Fada N'Gourma, Laboratory of Geoscience and Mining Environment (LaGE), Fada N'Gourma, Burkina Faso \\ ${ }^{2}$ University Joseph KI-ZERBO, Laboratory of Applied Chemistry and Biochemistry of Natural Products (LABIOCA), \\ Ouagadougou, Burkina Faso \\ ${ }^{3}$ University Joseph KI-ZERBO, Promotion Center for Development and Environmental Protection (CEPAPE), Ouagadougou, \\ Burkina Faso \\ ${ }^{4}$ University Joseph KI-ZERBO, Laboratory of Geoscience and Mining Environment (LaGE), Ouagadougou, Burkina Faso \\ Email: *reginakansole@gmail.com
}

How to cite this paper: Kansole, M. M. R., Compaore, M., Bagoro, A., Tamboura, M., Palenfo, K., \& Naba, S. (2021). Understanding the Artisanal Mining of the Pissy Granite Quarry Using the Problem-in-Context Framework (PiC). Journal of Geoscience and Environment Protection, 9, 35-45.

https://doi.org/10.4236/gep.2021.97003

Received: May 13, 2021

Accepted: July 17, 2021

Published: July 20, 2021

Copyright (๑) 2021 by author(s) and Scientific Research Publishing Inc. This work is licensed under the Creative Commons Attribution International License (CC BY 4.0).

http://creativecommons.org/licenses/by/4.0/

\section{(c) (i) Open Access}

\begin{abstract}
The Pissy granite quarry of Ouagadougou in Burkina Faso exists since 2006, and it is a source of financial incomes for many poor families working there. The Problem-In-Context framework $(\mathrm{PiC})$, lead the current study to understand better the quarry exploitation and structuration. Different motivations guide the quarry actors. Through those motivations, different solutions were suggested, mainly the shutdown of the quarry as the best way to decrease the impacts of the quarry exploitation on the environment, particularly regarding the air pollution and the loss of biodiversity in the area. The Pissy granite quarry is not recognized by the country's legislation and this study is presenting the site organization. They are three main actors on the site and the tertiary actors are the ones having more incomes comparing to the primary and secondary actors of the chain. There is a need to evaluate the shell life of the quarry if the shutdown is not the final option chosen by the country. This evaluation should be a way to restructure the field and to have more incomes from it. Many standards exist in the country to guide the quarries and mines exploitation but they do not have impact on the Pissy granite quarry because of its non-reorganization.
\end{abstract}

\section{Keywords}

Burkina Faso, Granite Mining, Quarry, Ouagadougou,

Problem-in-Context (PiC), Environment 


\section{Introduction}

United Nations Conference on Environment and Development (UNCED), Earth Summit, recognized that the Earth is the home of humanity (United Nations, 1992). In its principle 4 it states that "to achieve sustainable development, environmental protection must be an integral part of the development process and cannot be considered in isolation".

Economic development through production is the main source of environmental degradation (Mrabet, AlSamara, \& Jarallah, 2017). This is how the concept of sustainable development was born, attempting to reconcile Environment, Economy and Social. To make this reconciliation effective for financial institutions such as the International Monetary Fund, the World Bank now requires that all development projects should be submitted to an environmental study in order to identify potential environmental impacts (The World Bank, 2006). Thus, the project will be financed if the environmental impacts do not have irreversible negative effects on the environment. Several environmental impact analysis tools are adopted. Among them, the Environmental Impact Assessment (EIA), Life Cycle Assessment (LCA) and Strategic Environmental Analysis (SEAn) (Manuilova, Suebsiri, \& Wilson, 2009). The EIA is based on the assessment of the possible impacts of a project before it is carried out. As for Life Cycle Analysis, it is concerned with the assessment of the environmental impacts of a product from its extraction to disposal. The Strategic Environmental Analysis, on the other hand, was developed in response to the limitations of the Environmental Impact Assessment. SEAn is a proactive method that gives decision-makers an idea of the ecological situation of the area so that they can take it into account before making any plan of development (Kessler, 2003). In other words, SEAn is a pillar on which EIA must be built. SEAn method involves the problem in its context (Problem-in-Context/PiC). PiC allows an in-depth analysis of an environmental problem in its context in order to find adequate solutions (Sutton, 2012).

This article focuses on an environmental problem related to air pollution, in the Pissy district of Ouagadougou in Burkina Faso country. The PiC environmental analysis tool will be utilized to set the actors, causes, motivations, and solutions of the mining activity in order to decrease the environment pollution in the area.

\section{Methodology}

\subsection{Social Context}

Ouagadougou like other cities in the world is affected by strong urbanization (Kelder, 2011). For the city development, asphalting projects have been implemented. In the process of asphalting, and to reduce construction costs, the quarry located near the Société Nationale Burkinabè d'Hydrocarbure (SONABHY) is exploited (Figure 1). The populations have devoted themselves to artisanal exploitation of the site in order to supply the city with materials for building infrastructure. 


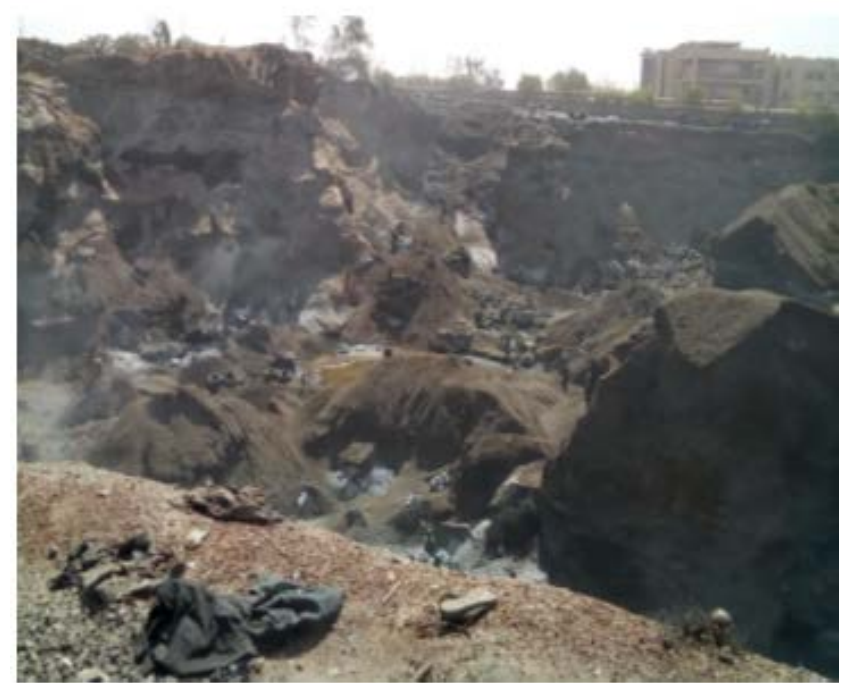

Figure 1. The open-pit of the Pissy granite quarry.

Nowadays, the exploitation of the granite quarry is the only artisanal activity present in the city of Ouagadougou. It is a source of income for the populations who practice the activity and at the same time makes it possible to supply the city for its construction needs in terms of gravel. However, the artisanal exploitation that is located in the heart of the city is not without consequences on the environment (air), and the lives of the populations. Granite is utilized in diverse forms (pebbles, fine sand) (Joel, 2010).

\subsection{Site Presentation}

The Pissy quarry, geographically behind the Société Nationale Burkinabè d'Hydrocarbure (SONABHY), is a place where men and women exploit granite on a daily basis for their living. Located in the heart of the city, it is located in sector 27 in the number 6 district of the capital (Figure 2). Its GPS coordinates are 12.345895 and -1.56654 . It stretches almost $700 \mathrm{~m}$ long and $70 \mathrm{~m}$ wide (Balade, 2021). This artisanal mining site is worth 36 years of operation.

The quarry has variable depth that can be only $30 \mathrm{~m}$ deep. A group of six (06) people who were the first to devote themselves to the operation manages the operation of the site. This granite quarry in the Pissy district is a called artisanal mining site because only manual mining methods are utilized in there to remove the granite from the ground, and so along the transformation chain on the site. This quarry has existed since the colonial time and the techniques have not changed yet. The operation of the Pissy granite quarry brings together nearly 3000 to 4000 people of all ages (children, young people, adults and old people) and genders. They usually work there with their families.

Every day men and women descend into the crevasse to bring out granite and crush it by hand. This work requires a physical strength to which they devote themselves for their survival. 


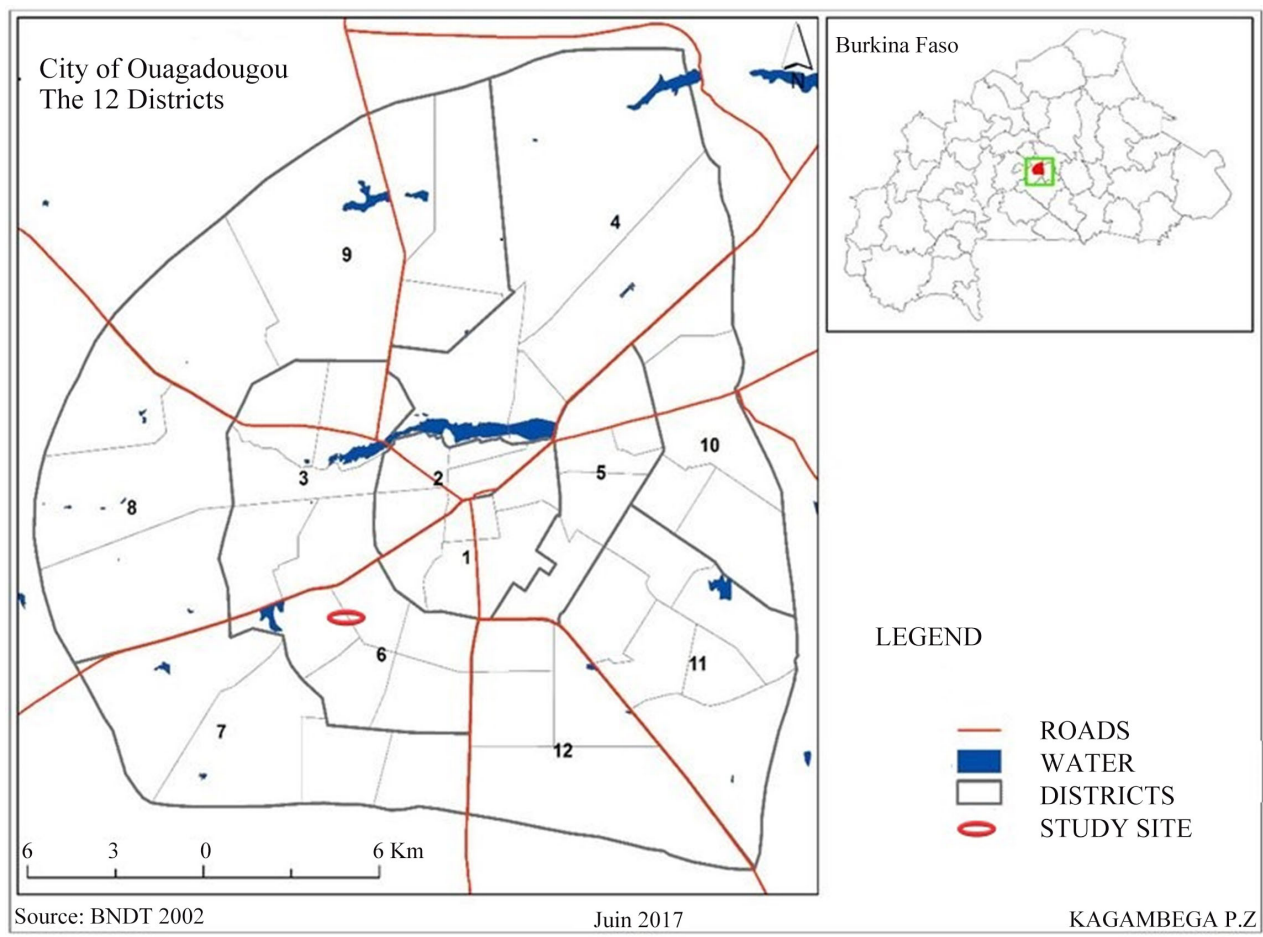

Figure 2. Location of the Pissy Granite quarry (the figure is adapted from Soma et al., 2017 (Soma et al., 2017)).

The operators of the granite quarry have an association called "la roche". This association brings together all the site workers. It was able to set up an infirmary, a nursery school and a primary school in order to be able to educate the children of the workers on the site.

\section{Results and Discussion}

\subsection{Environmental Problem Identification}

Air pollution is a very worrying environmental problem in the city of Ouagadougou (Boman et al., 2009). This pollution has several sources, mainly due to the transportation: leading to serious health issues (Bruce et al., 2000). The Pissy quarry activity leads to the rejection of carbon monoxide (CO) (Rinku Verma et al., 2016) from the combustion of plastics, which are usually old unused shoes (Figure 3(a)) and old unused tires (Figure 3(b)).

In fact, the plastics are utilized to weaken the granite in order to break it down easily (Figure 4(a), Figure 4(b)).

The burning of the granite pollute the air, leading the neighborhood to complain about the quarry activities regularly. In addition, the air pollution leads to diseases such as asthma, bronchitis ... (Bruce et al., 2000) and not only the workers at the quarry are exposed, but the entire neighborhood, mainly the children who are more fragile.

The Pissy quarry has lost its biodiversity due to the site exploitation and the environment bad quality, but also due to the soil that is no more fertile. 


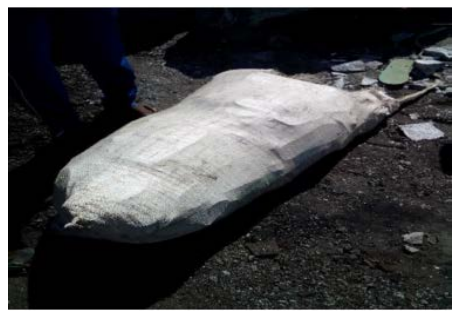

(a)

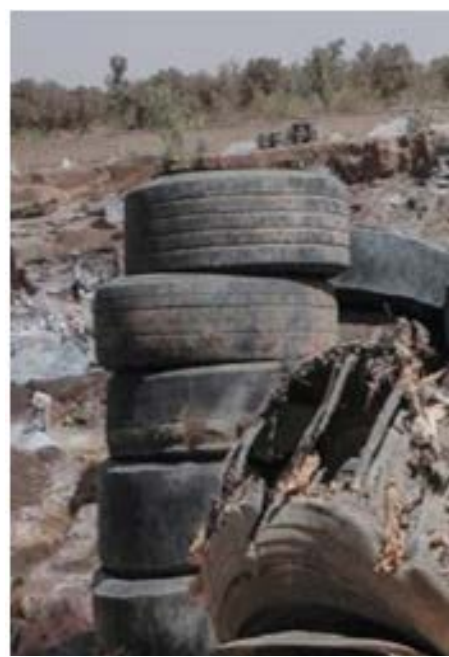

(b)

Figure 3. (a) Plastic shoes utilized as granite burners; (b) Old tires utilized as granite burners.

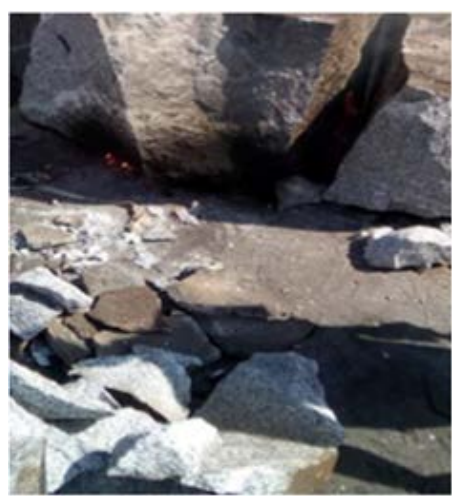

(a)

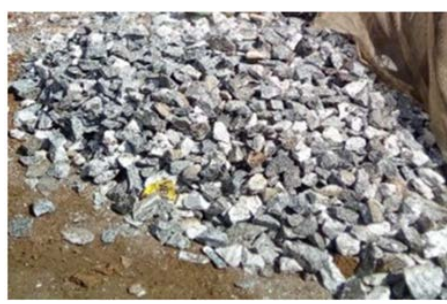

(b)

Figure 4. (a) Granite heated up; (b) Crushed granite. 


\subsection{Identification of the Activity Causes}

\subsubsection{Social Causes}

The Pissy quarry activity is a source of atmospheric pollution, and this is related to the artisanal exploitation of the site. The main actors of the site are poor people of all ages and genders due to poverty in general. During our investigations, we noticed that the majority of the workers were returnees from the neighbor country Côte d'Ivoire because of a political instability since 2001 .

\subsubsection{Physical Causes}

The physical causes of this activity are correlated with the growing urbanization of the city of Ouagadougou. The population explosion combined with the urbanization of the city of Ouagadougou is leading to a scarcity of arable land. In doing so, the town's peasants are brought into other activities such as trade, masonry, granite quarrying, etc. Indeed, most of the fields have become plots. This is what justifies this artisanal exploitation of the Pissy granite quarry. Another physical cause can be explained by the fact that the site is full of great granite potential, which justifies the artisanal exploitation of granite in this place.

\subsection{Identification of Actors Involved in the Process}

For artisanal granite mining, several actors are involved and play a particular role depending on the task they do. Various actors intervene on the site: granite burners, granite crushers, granite transporters and the granite buyers. These workers can be also classified as primary, secondary and tertiary actors.

\subsubsection{Primary Actors}

The primary actors are:

Granite burners and splitters: Block granite burners and splitters are usually adult men whose role is to shatter the granite blocks. These actors use a mixture of mud and old tires on the rock that they burn during about three days. The heat released makes the granite brittle and allows these men to split it with a hammer weighing about eight $(08 \mathrm{Kg})$ into large blocks. These large blocks will be burnt with the old rubber shoes to more easily split them into smaller blocks. The actors remove small slabs of granite that they will sell to women and to people for construction at a price of 10 FCFA per heap.

Granite crushers: These actors are generally women, children and elders. Although this work is tedious, it requires less physical effort than other tasks like splitting large blocks of granite, carrying the granite out of the open pit. Since this quarry is located in the heart of the city, thus close to homes, it is impossible to use explosives to facilitate the work in the quarry. This makes the work very hard and dangerous.

The young people to break the large pieces of granite into smaller blocks do the crushing first with a strong hammer. The women break up the pieces to reduce them to small pebbles called gravel, using small hammers. These little pieces are the finished product of a long process and are sold for 1000 FCFA. Women represent the majority of workers in the Pissy granite quarry. 
Granite carriers: The role of these actors is to transport the small blocks of granite out of the mining hole. These actors transport these small blocks on their heads.

\subsubsection{Secondary Actors}

The secondary actors are the intermediaries. They are generally adult men and they do not work directly in the exploitation of granite. However, they are mainly responsible for the marketing of the finished product. The crushers directly sell $15 \mathrm{Kg}$ of granite for $2000 \mathrm{FCFA}$, leading the women to complain because they do not make substantial profits by selling their products much more to these intermediaries.

\subsubsection{Tertiary Actors}

The intermediaries pile the gravel in large heaps. These piles of gravel will be resold to various potential buyers who will use them in construction, as well as other blocks that will be utilized for concrete and for buildings construction. These different potential buyers are real estate developers for construction.

\subsection{The Motivations and Options of the Actors}

Primary actors are the poorest people. Their motivation is to have an income to meet their basic needs (food, shelter, health care), and for their children's education.

Secondary actors are the intermediaries, in other words, the resellers on the site. They are those who buy the granite from primary actors and resell them to tertiary actors. They are those who make the greatest profit from the activity.

Tertiary actors are the last actors in the process of the granite exploitation. Their motivation is to have granite for the construction purpose.

\subsection{The Options}

The different actors have diverse options. Many alternatives are suggested to the primary and secondary actors, and among them, they are trading, guarding, masonry, gardening. However, tertiary actors find that artisanal quarrying is the best option that they can get. The women who work on the site need microcredits in order to carry out income-generating activities that will allow them to leave the site.

\subsection{Environmental Effects Analysis}

The artisanal mining of the Pissy quarry generates many environmental problems. For instance, soil degradation and the loss of biodiversity. In our context, the main problem is air pollution in the area. This is due to the release of harmful gases from the combustion of tires utilized for the granite extraction. This pollution is not without effects on human health (respiratory diseases) (Bruce et al., 2000). The toxic chemicals released by the combustion of tires and rubber shoes include:

Carbon dioxide $\left(\mathrm{CO}_{2}\right)$ : It is a colorless and odorless gas and in itself non-toxic. Since $\mathrm{CO}_{2}$ is the main greenhouse gas, it strongly contributes to glob- 
al warming (United States Environmental Protection Agency (EPA), 2021). In addition to climate change, the increase in $\mathrm{CO}_{2}$ emissions is at the origin of acidification phenomena (Union of concerned scientists, 2019).

Carbon monoxide (CO): It is due to the incomplete combustion of the tires, due to insufficient oxygen (Puneet Verma et al., 2018). It is an environmental toxic pollutant and contributes to the greenhouse effect.

Volatile Organic Compounds (VOCs): They are part of the family of pollutants having big diversity and great complexity. They have direct and indirect impacts on environment and human health (Bruce et al., 2000).

Nitrogen oxides (NOx): They are emitted on the site are due to the combustion of materials utilized for the embrittlement of the granite. Nitrogen dioxide NO2 has particular health impact on the respiratory tract (Boman et al., 2009). The NOX leads also to acid rain phenomena, and they are greenhouse gases as well (United States Environmental Protection Agency (EPA), 2021).

Solid particles (PM): They refer to the fraction of the components suspended in the gaseous medium. They are mainly PM10 and PM2.5. The latest penetrate deep into the respiratory system. Ultrafine particles are suspected of causing cardiovascular effects as well (Bruce et al., 2000).

Persistent Organic Pollutants (POPs): These include dioxins and furans from the incineration of solid plastic waste (Rinku Verma et al., 2016).

\subsection{Normative Context}

A new mining code that was adopted by law $036-2015 / C N T$ of June 26, 2015 in Burkina Faso governs the exploitation of mines and quarries in the country (Burkina Faso, 2015). In accordance with this law, we have the decree No. 2001-185/PRES/PM/MEE fixing the standards for the discharge of pollutants in the air, water and soil (Burkina Faso, 2001). This decree sets the various standards for discharges of substances from mining and quarrying into water, air and soil, as well as the thresholds not to be exceeded.

In addition, the decree No. 2017-0036/PRES/PM/MEMC/MATDSI/MINEFID/ MEEVCC/MCIA (Burkina Faso, 2017) on the management of mining permits and authorizations sets the standards for quarries exploitation in Burkina. The permit for the quarries exploitation must be renewed every 2 years considering the article 319 of decree No. 2017-0036 on the management of mining permits and authorizations. The Pissy granite quarry has not been officially authorized for exploitation. Nonetheless, the President of the National Assembly of Burkina Faso, in 2018 has visited the quarry to encourage site workers despite numerous nonconformities of the quarry.

\subsection{The Solutions}

Regarding the environmental effects resulting from the artisanal mining of the Pissy quarry in Ouagadougou, it is necessary to find solutions to overcome these effects:

- Close the site and find jobs for those who work there. We believe that it 
would be better to close the site by creating jobs for the primary actors especially. Young people can be assigned to trade schools for training. For the elderly, financially support them in entrepreneurship through projects;

- Modernize the operation of the site by providing operators with adequate modern equipment;

- Make site workers aware of the dangers associated with their operating methods;

- Identify another site if possible in provinces far from homes to relocate the workers;

- Plant trees around the site so that they can capture the carbon that escapes from the combustion of the tires in order to increase the air quality in the area;

- Follow the legislation;

- Further, study the environment quality in order to make adequate decisions.

Figure 5 summarizes the Problem-in-Context framework flowchart of the Pissy granite quarry and it shows how the problem of the granite exploitation, particularly in Burkina Faso.

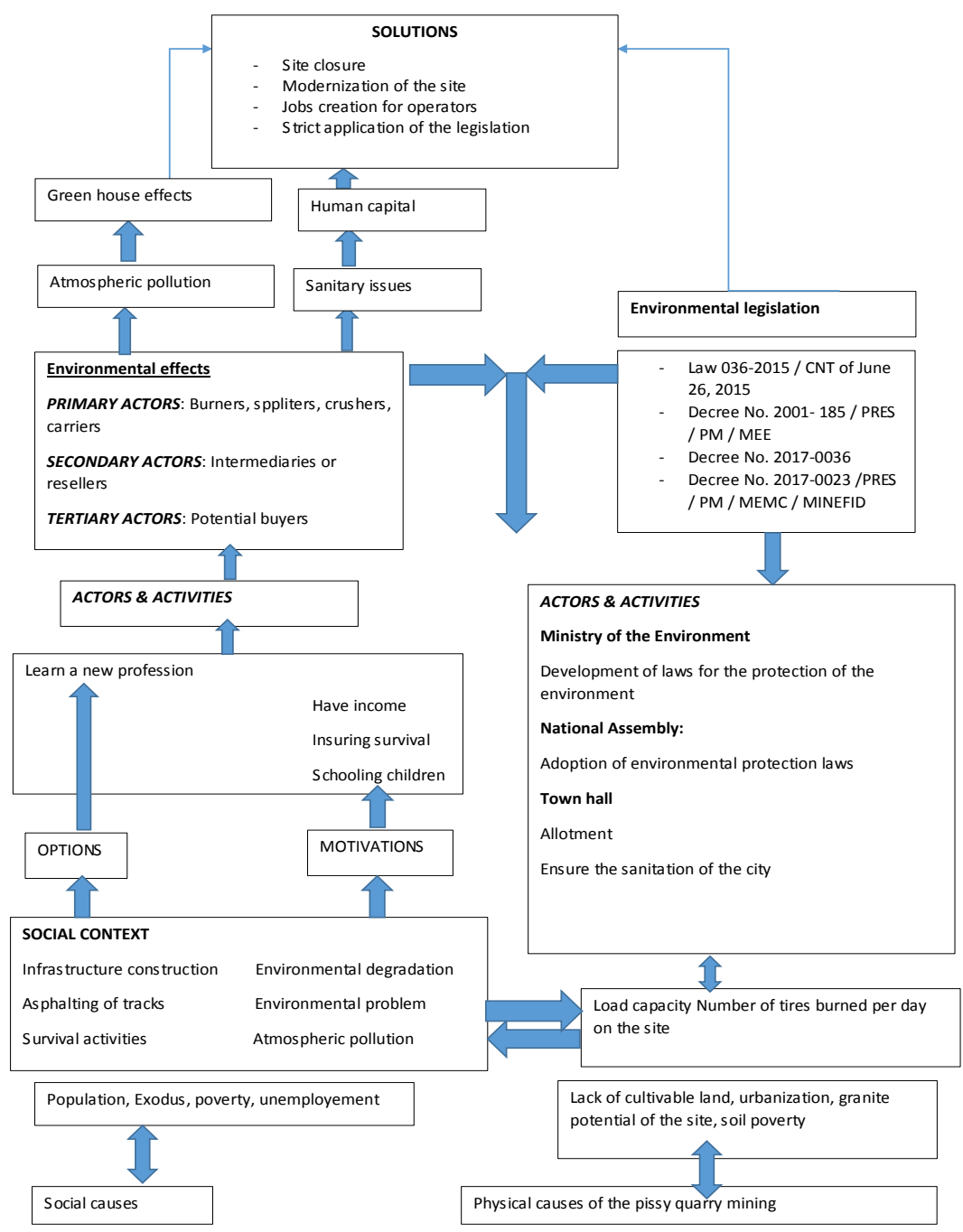

Figure 5. Problem-in-Context framework flowchart of the Pissy granite quarry. 


\section{Conclusion}

The Pissy granite quarry is a source of environmental pollution. The quarry is not recognized by the existing legislation and a lot is unknown about the site's organization. The site is a source of local population inconvenience due to a bad air quality. The Problem-in-Context $(\mathrm{PiC})$ framework has been a better way to understand the structuration of the workers in the quarry. The main reason that explains the existence of the quarry is poverty. Nonetheless, in the different solutions we suggested, it will be better to shut down the quarry in order to protect the environment and to protect the workers from respiratory diseases, but also to protect the biodiversity to get back in the area. In conclusion, the local politics should take a deep look under the Pissy granite quarry.

\section{Acknowledgements}

The University of Fada N'Gourma (Burkina Faso) supported this study.

\section{Conflicts of Interest}

The authors declare no conflicts of interest regarding the publication of this paper.

\section{References}

Balade, S. (2021). La carrière de Granit de Pissy. Sandrine Balade.

Boman, J., Lindén, J., Thorsson, S., Holmer, B., \& Eliasson, I. (2009). A Tentative Study of Urban and Suburban Fine Particles (PM2.5) Collected in Ouagadougou, Burkina Faso. X-Ray Spectrometry, 38, 354-362. https://doi.org/10.1002/xrs.1173

Bruce, N., Perez-Padilla, R., \& Albalak, R. (2000). Indoor Air Pollution in Developing Countries: A Major Environmental and Public Health Challenge. Bulletin of the World Health Organization, 78, 1078-1092.

Burkina Faso (2001). DECRET No 2001-185/PRES/PM/MEE/Portant fixation des normes de rejets de polluants dans l'air, l'eau et le sol.

Burkina Faso (2015). Loi No 036-2015/CNT portant code minier du Burkina Faso.

Burkina Faso (2017). Decret NO 2017-0036/PRES/PM/MEMC/MATDSI/MINEFID/ MEEVCC/MCIA portant gestion des titres miniers et autorisations.

Joel, M. (2010). Use of Crushed Granite Fine as Replacement to River Sand in Concrete Production. Leonardo Electronic Journal of Practices and Technologies, 17, 85-96.

Kelder, Y. (2011). The Ecology of Urbanization: The Case of Ouagadougou, Burkina Faso. Master's, Roskilde: Department of Environmental, Social and Spatial Change.

Kessler, J. J. (2003). Working towards SEAN-ERA: A Framework and Principles for Integrating Environmental Sustainability into Planning.

Manuilova, A., Suebsiri, J., \& Wilson, M. (2009). Should Life Cycle Assessment Be Part of the Environmental Impact Assessment? Case Study: EIA of $\mathrm{CO}_{2}$ Capture and Storage in Canada. Energy Procedia, 1, 4511-4518. https://doi.org/10.1016/j.egypro.2009.02.269

Mrabet, Z., AlSamara, M., \& Jarallah, S. H. (2017). The Impact of Economic Development on Environmental Degradation in Qatar. Environmental and Ecological Statistics, 24, 7-38. https://doi.org/10.1007/s10651-016-0359-6 
Puneet Verma, A. Z., Jafari, M., Bodisco, T. A., Rainey, T., Ristovski, Z. D., \& Brown, R. J. (2018). Diesel Engine Performance and Emissions with Fuels Derived from Waste Tyres. Scientific Reports, 8, Article No. 2457.

https://doi.org/10.1038/s41598-018-19330-0

Rinku Verma, K. S. V., Papireddy, M., \& Gowda, A. N. S. (2016). Toxic Pollutants from Plastic Waste-A Review. Procedia Environmental Sciences, 35, 701-708.

https://doi.org/10.1016/j.proenv.2016.07.069

Soma, A., Wend-bénédo Tapsoba, F., Kabore, D., Seogo, I., Tankoano, A., Hama Dicko, M., Sawadogo, H. et al. (2017). Etude sur la capacité de production, du circuit de commercialisation et de la consommation du zoom-koom vendu dans la ville de Ouagadougou au Burkina Faso. International Journal of Biologycal and Chemical Science, 11, 2294-2305. https://doi.org/10.4314/ijbcs.v11i5.27

Sutton, I. (2012). Safety and Environmental Management Systems. In I. Sutton (Ed.), Offshore Safety Management: Implementing a SEMS Program (pp. 102-172). Amsterdam: Elsevier. https://doi.org/10.1016/B978-1-4377-3524-6.00004-6

The World Bank (2006). Environmental Impact Assessment Regulations and Strategic Environmental Assessment Requirements.

Union of Concerned Scientists (2019). $\mathrm{CO}_{2}$ and Ocean Acidification: Causes, Impacts, Solutions.

United Nations (1992). Conference on Environment and Development Earth Summit.

United States Environmental Protection Agency (EPA) (2021). Overview of Greenhouse Gases. 